\title{
ストレス条件下の葉の光合成は ダンダラである!
}

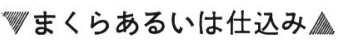

日頃，何げなく見ている高等植物の葉について，まず いくつかの数字をあげてみよう.

葉の厚さ，これはまちまちであるが，普通 $100 \mu \mathrm{m}$ か ら $500 \mu \mathrm{m}$ ぐらい. カエデなどの葉はもっと薄くなる場 合もある. ぼってりと厚い感じのホウレンソウの厚さが $1 \mathrm{~mm}$ 程度である. 葉の内部には, 光合成を行なう葉肉 細胞などが存在している. 葉の内部で細胞の占める体積 は普通 30〜70\%で，それ以外は細胞間陌とよばれる空 間である. 誤解されやすいことだが，細胞間隙は空気で 満たされているのであって, 水で満たされているのでは ない！葉肉細胞の表面は細胞間隙にさらされている が，葉面積に対する細胞間陌にさらされている葉肉細胞 表面積の比は, 10〜50 となる.このように, 葉の内部は 非常に入り組んでいる.

気孔は，水蒸気， $\mathrm{CO}_{2}$ などのガスが葉へ出入りする際 の通り道となっているが，その数は葉面積 $1 \mathrm{~mm}^{2}$ 当た り 100 個ぐらいである.もちろん,これは大ざっぱな目 安で，種によってあるいは生育する環境によって異な る. 気孔を葉の裏側にもつ植物が多いが, 表裏両側にも つ植物や，表側だけにもつものもある.

葉の光合成速度を葉面積当たりで表わすと, 飽和光下 で $4 \sim 40 \mu \mathrm{mol} \mathrm{CO} \mathrm{m}^{-2} \mathrm{~s}^{-1}$ 程度である. 葉が光合成 を行なっている時, 外気の $\mathrm{CO}_{2}$ は気孔を通って葉の内 部に入り, 細胞間隙 $\rightarrow$ 葉肉の細胞壁 $\rightarrow$ 細胞質という経路 をとって葉緑体に到達する. 光合成を行なっている時に は，葉は $\mathrm{CO}_{2}$ を吸収しているのだから，葉の内部の $\mathrm{CO}_{2}$ 分圧は外気中の分圧より低い.この外気中から葉緑 体への $\mathrm{CO}_{2}$ の輪送に括ける最大の抵抗は気孔の部分で あるといわれている(1). 気体中における $\mathrm{CO}_{2}$ の拡散はか なり速やかなので, 葉が薄く, 多くの気孔が開いている 場合には, 細胞間隙中の $\mathrm{CO}_{2}$ 分圧はほぼ一様である(2). たと㝋ば, 外気の $\mathrm{CO}_{2}$ 分圧が $350 \mu \mathrm{bar}$ の場合, 光合成 起行なっている葉の細胞間隙の $\mathrm{CO}_{2}$ 分圧は, C 3 植物で
200 230 $\mu \mathrm{bar}, \mathrm{C} 4$ 植物で $100 \mu \mathrm{bar}$ 程度になることが 多い, もちろん，葉が極端に厚い場合には，細胞間隙の $\mathrm{CO}_{2}$ 分圧は気孔に近い所よりも遠い所のほうが低くな る.

\section{将ストレス条件下の光合成瓜}

葉をストレス条件下におくと，一般には気孔が閉じ， 光合成速度が低下する。一言で気孔が “閉じる”といら けれども，そもそもこれがかなりの難物である。たと党 ば, 気孔が “開いて”いる時, 多くの気孔についてその 開度を測定し，その分布をとってみると，ベル型の分布 を示す (図 1-A). それでは，気孔が“閉じて”いる時 の開度の分布パターンはどうなるかというと, どうやら 図 1-B のような格好になるらしい(3).つまり，気孔が “閉じる”場合には, 完全に閉じた気孔と, 開いた気孔と が同時に存在するのである。このような場合には, 開い た気孔の間の距離は長くなるので, 横方向の $\mathrm{CO}_{2}$ 分圧 の低下が無視できなくなってしまう，つまり，開いてい る気孔の周辺の $\mathrm{CO}_{2}$ 分圧は，遠い部分のそれよりもか なり高くなる.

葉を太陽にかざして見ると，葉脈が網目状に透さ通っ て見える場合があるが，このよらな葉はへテロバリック

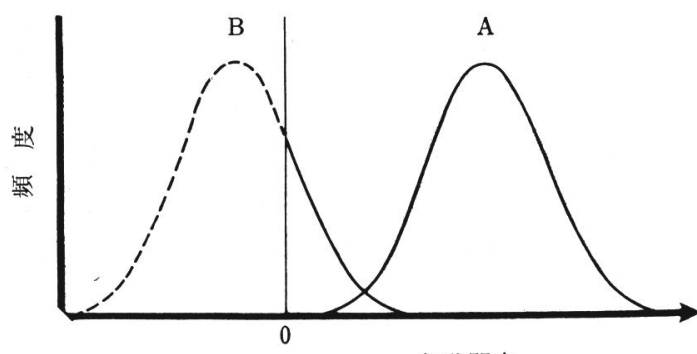

気孔開度

図 1-気孔開度の頻度分布

A：気孔が “開いて”いる時, B : 気孔が“閉じて”いる時. マイナスの気孔開度 (B, 破線部分) を仮定すれば, “閉じて” いる時の開度分布もぺル型の関数で表現できる（詳細は文献 ${ }^{(3)}$ 参照). 


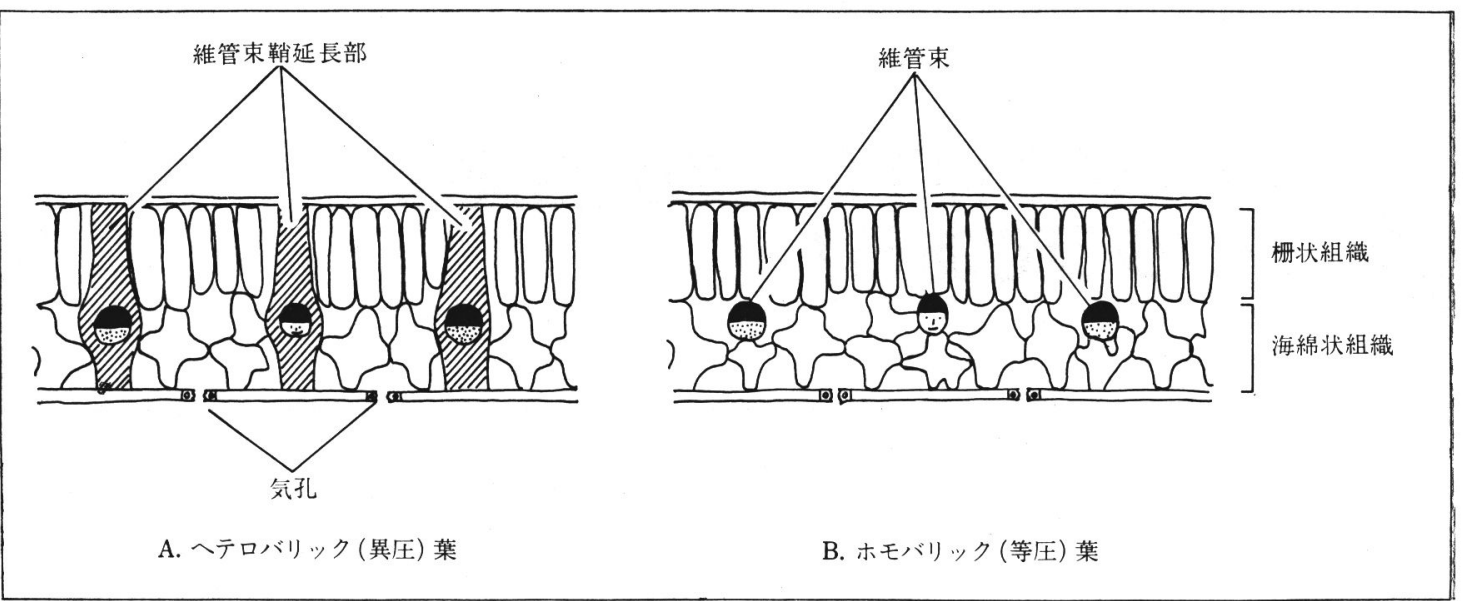

図 2-へテロバリック葉（A）とホモバリック葉（B） 斜線部が維管束延長部

葉とよばれ，その断面は 図 2-A に示すよらになってい て，葉脈を团む維管束鞘から維管束鞘延長部が両側の表 皮に伸びている.この維管束䩬延長部には細胞間隙がな いので, 葉肉の内部に拈けるガスの二次元方向への拡散 に対しては障壁となる。言い換壳れば，このような葉は， 維管束鞘延長部の壁によって数多くの小部屋にしきられ ているわけである，小部屋の大きさは種によって，また その生育環境によって様々である.小さいものでは, 小 部屋当たりの気孔の数がわずか 10 個注どである. した がって，さきほど考觉たように，開いている気孔の数が ごく少数になるような厳しいストレス条件下において は，単純な確率からいっても，開いた気孔を一個ももた ない小部屋が出現する.このような小部屋では, 光存在 下の細胞間隙の $\mathrm{CO}_{2}$ 分圧が, $\mathrm{CO}_{2}$ 補償点 (C 3 植物で は約 $30 \mu \mathrm{bar}, \mathrm{C} 4$ 植物では 0 に近い) に近づくので,ネ ット（正味）の光合成を行なうことができない。

一方, 開いた気孔をもつ小部屋は光合成を行なうこと ができる.図了は（おそらく）このようなメカニズムに よって生じた光合成によるデンプン生成のダンダラであ る. 材料はヒマワリ，根に起こる水ストレスの茥葉部へ の媒介者（?）として知られるアブシジン酸（abscisic acid）を葉柄から蒸散流を通して与学るといらモデルシ ステムを用いた実験の結果である.図 2-B に示したよ らなタイプのホモバリック葉にアブシジン酸を与える と, 全体的にデンプンの量は減少するものの, 眓 3 のよ らな顕著なダンダラはできない、(4).

アブシジン酸を用いたモデル実験に限って言えば，光 合成のダンダラは, 完全に気孔の閉鎖の不均一性, およ び葉肉内の $\mathrm{CO}_{2}$ の拡散に対して維管束䩱延長部が障壁
となることによるものである。つまり，完全に“構造 的”な要因によっている（アブシジン酸が葉肉細胞自身 の光合成能力にまったく影響を与兄ないことは，表皮を 剝離することによって, $\mathrm{CO}_{2}$ 払散に対する障壁を除外し た葉片の光合成活性が，アブシジン酸の有無に扣いて同 一であることによって証明された(4)).

このようなダンダラは, フブシジン酸を使ったモデル システムのみではなく, 塩ストレス, 水ストレス, ある いは光合成誘導期といった気孔が閉じる条件下で一般的 に起こることが，現在続々と証明されつつある.

従来, ガス交換法を用いた葉の光合成の研究では, 光 合成速度を外気の $\mathrm{CO}_{2}$ 分圧に対してのみではなく, 光 合成速度や蒸散速度の測定值などから計算によって求め

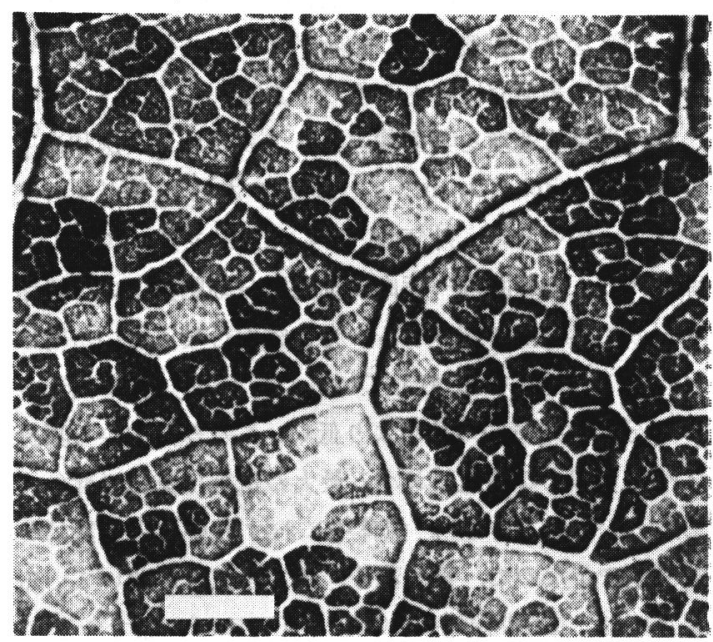

図 3・ヒマワリの葉にアブシジン酸を作用させた時に見られる デンプン生成のダンダラ

白線は $1 \mathrm{~mm}$ (詳細は文献 ${ }^{(4)}$ 参照) 
た細胞間隙の $\mathrm{CO}_{2}$ 分圧に対して評価することが行なわ れてきた．この方法をとれば，気孔の影響を受けない葉 肉自身の光合成能力が評価できると信じられていたから である、環境ストレスや薬剤が光合成に及汸す影響を研 究する際に，まずそ机らの要因が気孔の閉鎖をむたらす だけなのか，それとも葉肉の光合成にも影響を与えるの かを知ることが重要なので，この方法は過去 20 年間 非常にしばしば用いられてきた。しかし，細胞間隙の $\mathrm{CO}_{2}$ 分圧の計算は，葉に执いて光合成・蒸散が均一飞起 こることを仮定（と言うよりは，当然のことと）してい るので(1)，光合成・蒸散がダンダラである場合の計算值 はまったく信用できない，ここでは詳しく述べないが， 計算值はつね汇過大評価となる(4)。したがって，ガス交 換法を用いて得られた “○×要因は気孔閉鎖をもたらす とともに，葉肉の光合成能力も低下させる”といったよ らな結論は，すべて疑問視しなければならない，光合成 のダンダラの発見は, この種の研究をやってきた人たち には，かなりショッキングな事件であったようだ.

\section{勿余談あるいは本音瓜}

ところで，この光合成のダンダラ現象について，筆者 自身が興味をっていることは，気孔の開度分布に関す るものである、生物現象には幅があるのだ，といってし ま光ばそれまでなのかもしれないが，(1)閉でやすい気孔 と開きやすい気孔とのあいだの本質的な違いは何か? (2)閉じやすい気孔，開きやすい気孔は，いっもそれぞれ 閉じやすく開きやすいのか？それとも，そういった性 質は時間的に変化するのか？たと学ば，あるストレス からの回復後，またストレスをかけた場合には，同じパ ターンが得られるのか?……などは大変重要な問題であ る. 特に(2)については，気孔一個一個の顕微鏡観察が不 可欠である，近年著しい発展をみせている画像処理技 術(5) はこの種の研究にきわめて有効である.

筆者のもら一つの興味は, $\mathrm{CO}_{2}$ の側方拡散の障壁とな っている維管束鞘延長部が何をしているのかといらこと である. (1)光の通り道になっている. (2)病気の感染進行 を防ぐ障壁となっている. (3)葉脈から表皮への水の通り 道になっている……な゙の説があるが，いずれも決定的 な証拠に欠ける。あるいは，いろいろな役割がある，と いうのが本当なのかもしれない。

(1)は確かに事実ではある，葉の光合成有効放射の透過 率は数\%内外なので，葉の内部にはかなり急な光環境勾 配ができる，つまり，葉が明るい光を受けている時で も，葉の裏側の葉緑体は暗い光環境下にある，維管束鞘
延長部の細胞は，発達した葉緑体をもたないので，まさ に光ファイバーになっていて光がよく透過する. したが って, 維管束鞘延長部の近傍にある葉緑体は裏側に近い ものでる，かなり明るい光を享受することができる．こ の上うな光環境を均一化する方向は，葉全体の光合成の 効率を上昇させる( ${ }^{(6)}$.

一方，(2)が正しいと思われるような感染パターンをみ ることがよくある，維管束鞘延長部は，確かに菌系や線 虫の移動に対する障壁になっているようだ.

また，(3)の維管束鞘延長部が水の通り道になっている ことについては, 古くから指摘されている(7). 葉脈 $\rightarrow$ 維 管束鞘延長部 $\rightarrow$ 表皮 $\rightarrow$ 気孔 $\rightarrow$ 大気といら水の流れは葉肉 を迂回して郝り，土㙵や大気が乾燥した時に葉全体とし ての水ポテンシャルをあまり変化させずに気孔を閉じる といらメカニズムの基礎になっているのかもしれない。

とにかく，葉の光合成や蒸散について，特にそれらと 葉の構造との関係は，まだまだわからないことだらけで める、昨今流行の学問とは少々趣を異にする地味な分野 ではあるが，植物の生活の理解のためにはこういった学 問も不可久であるのに違いない。

謝辞：維管束鞘延長部の役割伔つて相談にのって下さった 森林総合研究所北海道支所の小池孝良博士に和礼申し上げます. 原稿を読んで下さった同僚の朴龍陸博士にる和礼申し上げすす。

1) G.D. Farquhar \& T.D. Sharkey: Annu. Rev. Plant Physiol., 33, 317 (1982).

2) D. F. Parkhurst, S.-C. Wong, G.D. Farquhar \& I. R. Cowan : Plant Physiol., 86, 1032 (1988).

3) A. Laisk, V.Oja \& K. Kull : J.Exp. Bot., 31, 49 (1980).

4) I. Terashima, S.-C. Wong, C. B. Osmond \& G.D. Farquhar : Plant Cell Physiol., 29, 385 (1988).

5) K. Omasa, Y.Hashimoto, P. J. Kramer, B. R.Strain, I. Aiga \& J. Kondo : Plant Physiol., 79, 153 (1985).

6) I. Terashima : 'Productive structure of a leaf', in "Photosynthesis", ed. by W. Briggs, Alan R. Liss, New York, 1989, in press.

7) R. B. Wylie : Amer.J. Bot., 39, 645 (1952).

(寺島一郎, 東京大学理学部) 